\title{
Artificial cyanobacterial mats: structure and composition of the biota
}

\author{
Tom Fenchel * \\ Marine Biological Laboratory (University of Copenhagen), Strandpromenaden 5, DK-3000 Helsingør, Denmark
}

\begin{abstract}
The structure of cyanobacterial mats growing in and on foam rubber (initiated with inoculates of defaunated sediments) is described by light and transmission electron microscopy. Different horizontal layers can be recognised which largely correspond to what has previously been described from stromatolitic mats in hyperhaline habitats, but phototroph diversity was lower than recorded from natural mats. The maximum volume fraction of filamentous cyanobacteria was found within the upper 100 to $200 \mu \mathrm{m}$ of the mat (about 10 or $25 \%$ when mucous sheaths are included); deeper in the mat (down to 3-4 mm where purple sulphur bacteria appear) their volume fraction was reduced to about about $1 / 3$ of that of the surface layer. The total length of cyanobacterial filaments beneath $1 \mathrm{~cm}^{2}$ mat is about $14 \mathrm{~km}$. Various types of cyanobacteria (chroococcoids, Phormidium, Microcoleus, and Nostoc) were present, but 2 morphospecies of Pseudoanabaena were quantitatively dominant in the studied mats. Vertical migration of the organism in response to changing light conditions probably played a minor role in these mats.
\end{abstract}

KEY WORDS: Cyanobacterial mats - Microscopic structure - Biotal composition

\section{INTRODUCTION}

Among many studies on cyanobacterial mats published during the last 2 decades, few are concerned with their spatial structure on a microscopic scale. A major obstacle has been to obtain thin sections of communities that usually contain mineral grains and frequently carbonate deposits. Attempts to imbed mats in resins and apply methods for obtaining thin sections of geological specimens (Wachendörfer \& Krumbein 1991) yield results with limited resolution and quality. Scanning electron microscopy has given interesting and attractive images of the 3 -dimensional structure of mats at different depths (Jørgensen et al. 1983, Stal et al. 1985), but yields little information on the organisms and cannot readily be used for quantitative estimates. Transmission electron microscopy (TEM) of limited parts of mats or of isolated organisms (Stolz 1983, 1990, 1994, Nicholson et al. 1987, D'Amelio et al. 1989) has primarily provided information on the diversity of mat

\footnotetext{
•E-mail: mbltf@inet.uni2.dk
}

biota, but the method has been limited by the difficulty of making ultrathin sections.

The present paper describes the spatial structure and biotal composition based on histological sections of cyanobacterial mats growing on and in foam rubber in combination with observations on living mat components.

\section{MATERIAL AND METHODS}

The inoculate for the mats was defaunated sediments from the shallow brackish Nivå Bay $15 \mathrm{~km}$ south of Helsingør, Denmark (see Fenchel 1998a for methods) and the mats were maintained as described in Fenchel (1998a). The sectioned mat was about 4 mo old and grew in and on a $4 \mathrm{~mm}$ thick foam rubber plate (the mat had at that time grown about $0.7 \mathrm{~mm}$ above the foam rubber surface while the purple zone extended below the foam rubber and into the underlying sand). Vertical slices corresponding to a surface area of approximately $2 \times 5 \mathrm{~mm}$ were cut with a scalpel and fixed in $3.5 \%$ glutaraldehyde and $1.5 \% \mathrm{NaCl}$ in $0.2 \mathrm{M}$ 

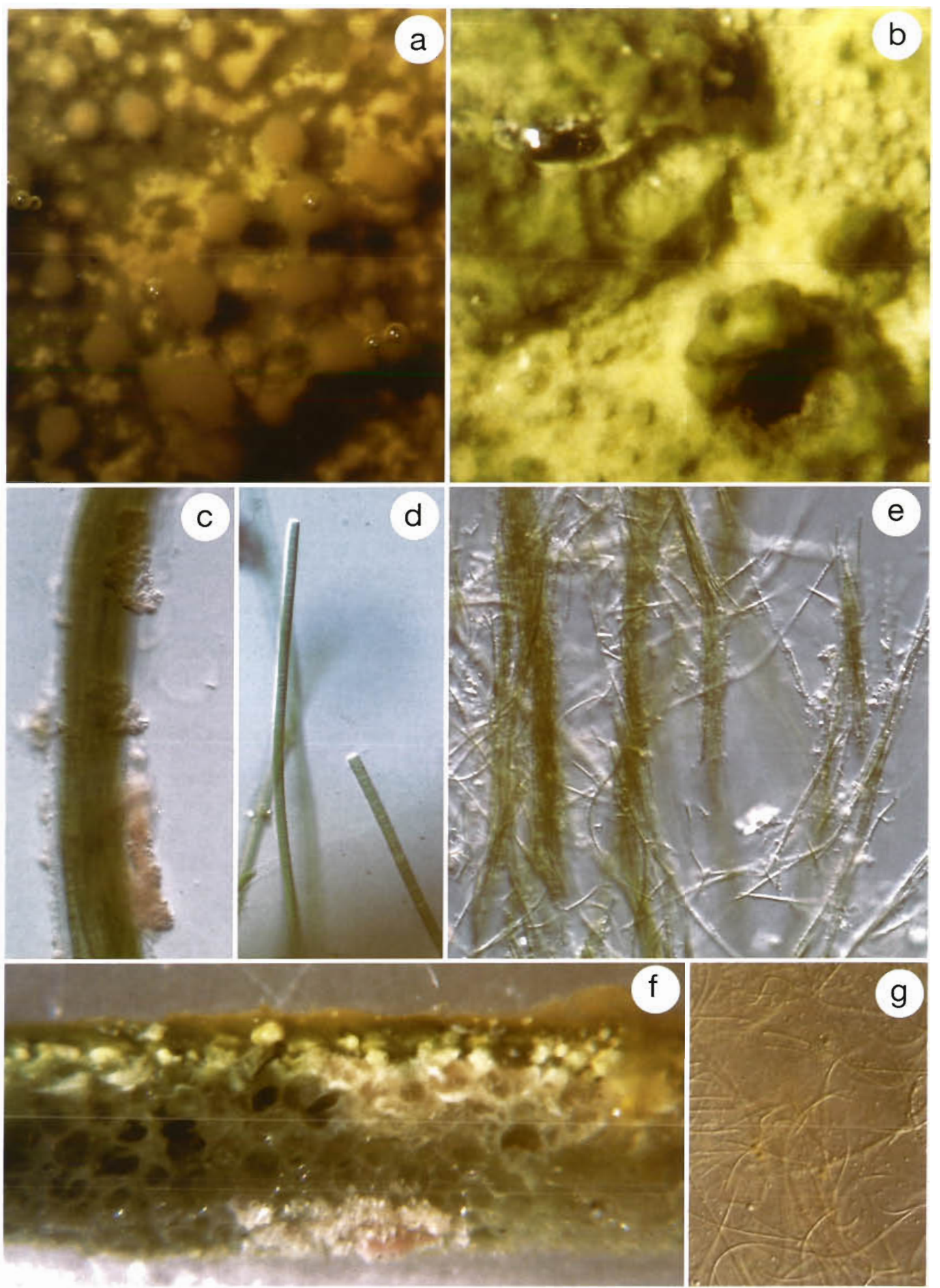

Fig. 1 (a) Surface of a mature mat; the pinnacles are about $1 \mathrm{~mm}$ in diameter; the light patches show the underlying carbonate deposits. (b) Surface of an approximately 1 mo old mat with blisters formed by $\mathrm{O}_{2}$ bubbles. (c) Microcoleus colony (diameter: $70 \mu \mathrm{m}$ ) with attached purple sulphur bacteria. (d) Phormidium filaments (diameter: $7 \mu \mathrm{m}$ ). (e) Bundles of the deep morphotype of Pseudoanabaena (diameter of individual filaments: $1 \mu \mathrm{m}$ ). (f) Section through a mat growing in and on $4 \mathrm{~mm}$ thick foam rubber; the deeper extension of the white layer (carbonate particles) to the right is probably an artefact resulting from slicing the mat with a scalpel; in the bottom some adhering sand grains with purple bacteria are seen. (g) A mucus pinnacle with the surface morphotype of Pseudoanabaena (diameter: $1 \mu \mathrm{m}$ ) 
pH 7.5 phosphate buffer followed by postfixation in buffered $1 \% \mathrm{OsO}_{4}$. The fixed specimens were rinsed in $\mathrm{H}_{2} \mathrm{O}$, dehydrated, embedded in epon and sectioned on an ultramicrotome (LKB). The $4 \mathrm{~mm}$ deep sections were cut perpendicular to the mat surface. For light microscopy, $2 \mu \mathrm{m}$ sections were used after staining in a toluidine blue solution prior to dehydration and mounting in DPX. For TEM, $0.1 \mu \mathrm{m}$ sections were stained in a saturated solution of uranyl acetate in ethanol and viewed in a Zeiss EM900 electron microscope.

Estimates of volume fraction of different mat constituents were based on area fractions measured by planimetry on TEM photographs (Aherne \& Dunhill 1982). Such estimates were made on a series of 10 photographs, each covering an area of $25 \times 25 \mu \mathrm{m}$ perpendicular to the surface (together covering the upper $0.25 \mathrm{~mm}$ of the mat), on a similar series situated about $1 \mathrm{~mm}$ beneath the mat surface, and on some individual photographs at different depths in the mat.

Additional observations were made on live material removed from the mat with steel needles or forceps. Such observations were made regularly on mats of different ages growing on sand as well as on foam rubber. Identification of cyanobacteria was based on Anagnostidis \& Komárek (1988) and Komárek \& Anagnostidis $(1986,1989)$.

\section{RESULTS AND DISCUSSION}

The surface of young mats was yellowish or light green and blistered due to the generation of $\mathrm{O}_{2}$ bubbles (Fig. 1b). After about 3 wk, mucous 'pinnacles' up to $2 \mathrm{~mm}$ tall appeared and after about 2 mo the surface became yellow or brownish with lighter areas where carbonate deposits (at a depth of 200 to $300 \mu \mathrm{m}$ ) were visible through the mat surface (Fig. 1a).

A schematic presentation of the vertical structure of a 4 mo old mat is shown in Fig. 2; see also Figs. 1 f \& 3. The light brown pinnacles consisted of mucous material embedding bacteria and relatively few Pseudoanabaena filaments, chroococcoids (Fig. 1f), and some of the eukaryotic constituents (see below). The surface of the pinnacles also often harboured colonies of Nostoc which did not seem to occur anywhere else

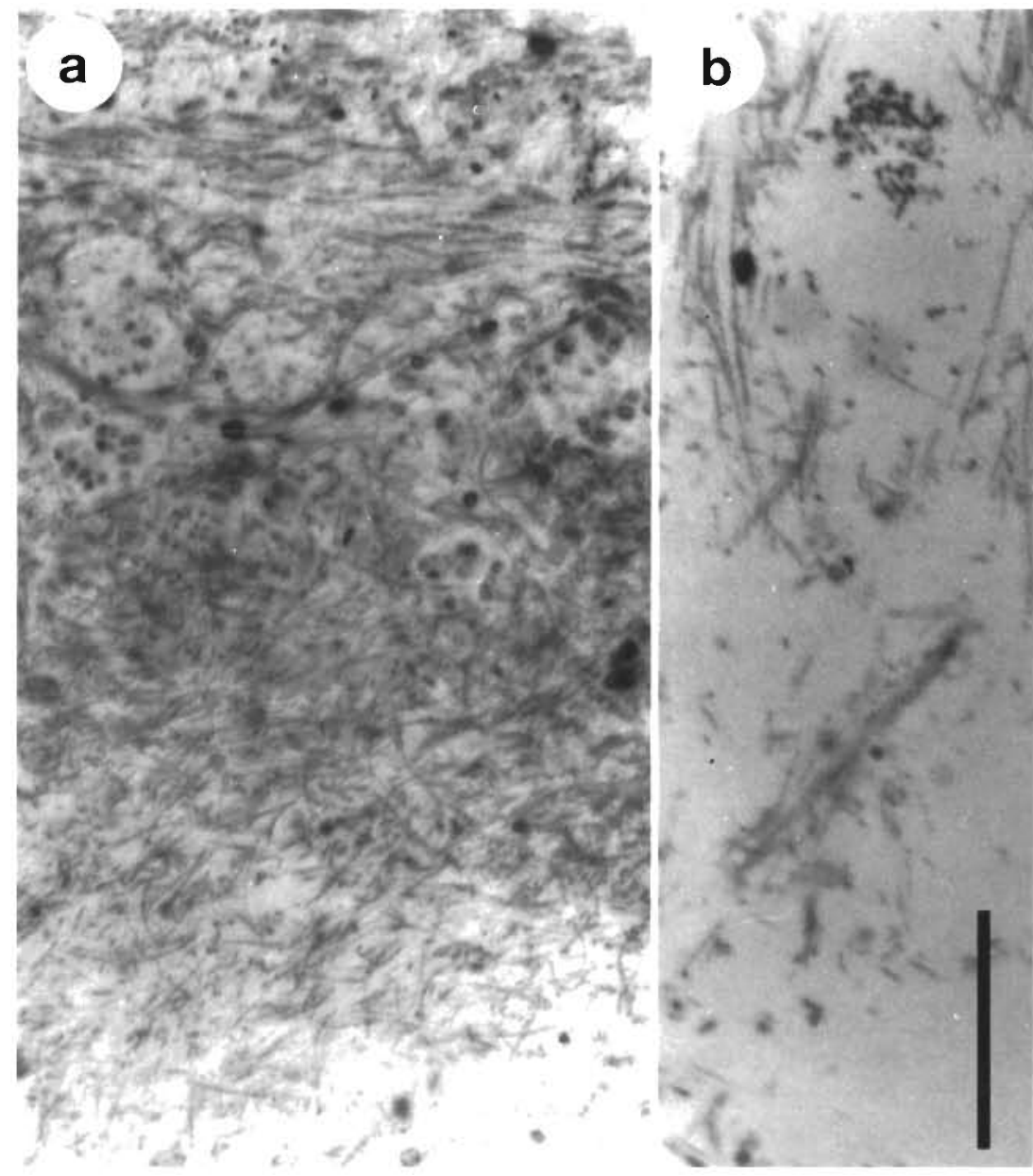

Fig. 3. Sections of the fixed mat in the light microscope; (a) from the surface to $0.25 \mathrm{~mm}$ depth; (b) between 0.32 and $0.77 \mathrm{~mm}$ depth. Scale bar: $50 \mu \mathrm{m}$ 

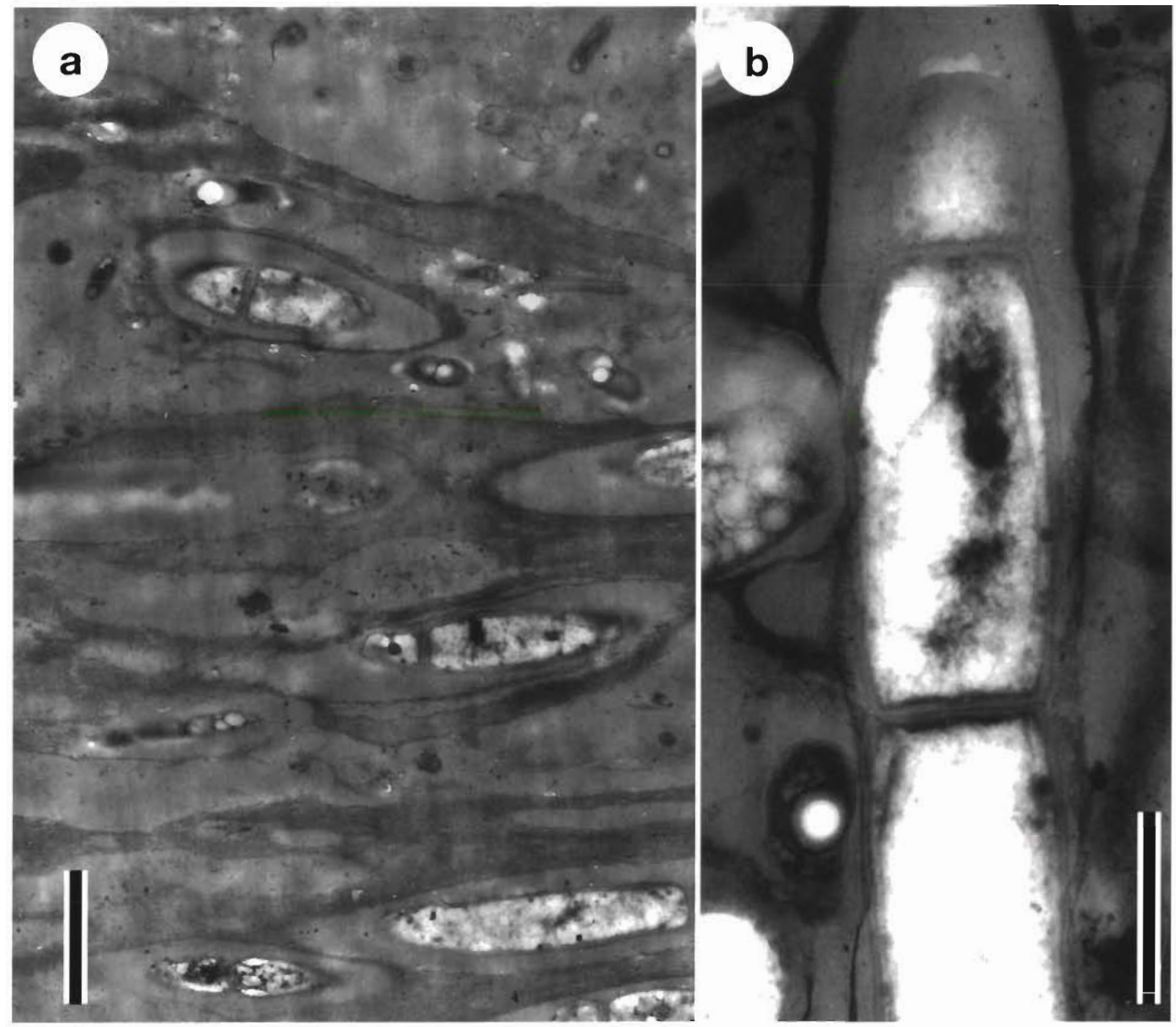

Fig. 4. (a) Deepest part of the mucous pinnacle layer (above) the parallel layer of cyanobacterial filaments. Scale bar: $2 \mu m$. (b) Pseudoanabaena morphotype found in the surface layer of the mat. Scale bar $1 \mu \mathrm{m}$

in the mats. Similar pinnacles are also a feature of some naturally occurring cyanobacterial mats (Javor \& Castenholz 1981).

Below the layer with mucous pinnacles there was a smooth horizontal surface $(0 \mathrm{~mm}$ depth in Fig. 2); beneath it the mat had a light brownish colour down to a depth of 0.25 to $0.35 \mathrm{~mm}$. This layer was totally dominated by filaments belonging to one of the 2 morphospecies of Pseudoanabaena (Figs. 4a, b, 5a \& 6a). The living filaments appeared almost colourless, but fluorescence microscopy revealed the presence of chlorophyll as well as of phycoerythrin although these pigments were present at much lower concentrations than in filaments living deeper in the mat. The filaments were $1.0 \mathrm{\mu m}$ in diameter and surrounded by mucous sheaths. In the upper $30 \mu \mathrm{m}$ of this zone many sheaths were empty; at this level all filaments were oriented parallel to the surface (Figs. $3 \& 4$ a) and contained relatively few other types of bacteria. The greatest density of filaments occurred beneath this 'parallel layer' and down to a depth of approximately $0.3 \mathrm{~mm}$ (Figs. $5 \mathrm{a}$ $\& 6 a)$. At this level the filaments appeared to have a random orientation. The space between the cyanobacterial sheaths also contained mucous material as well as numerous other, presumably mainly heterotrophic, bacteria. These were often found adhering to the outer surface of the sheaths (Fig, 4b), but none were found inside. At these depths Pseudoanabaena filaments had poorly developed thylakoids (e.g. Fig. 4b) in accordance with their low chlorophyll content.

Beneath $0.3 \mathrm{~mm}$ depth the mat turned light green and the other morphotype of Pseudoanabaena appeared (Figs. 5b, 6b, $c \& 7 a$ ). It had the same cell diameter as the form inhabiting the surface layers. The 

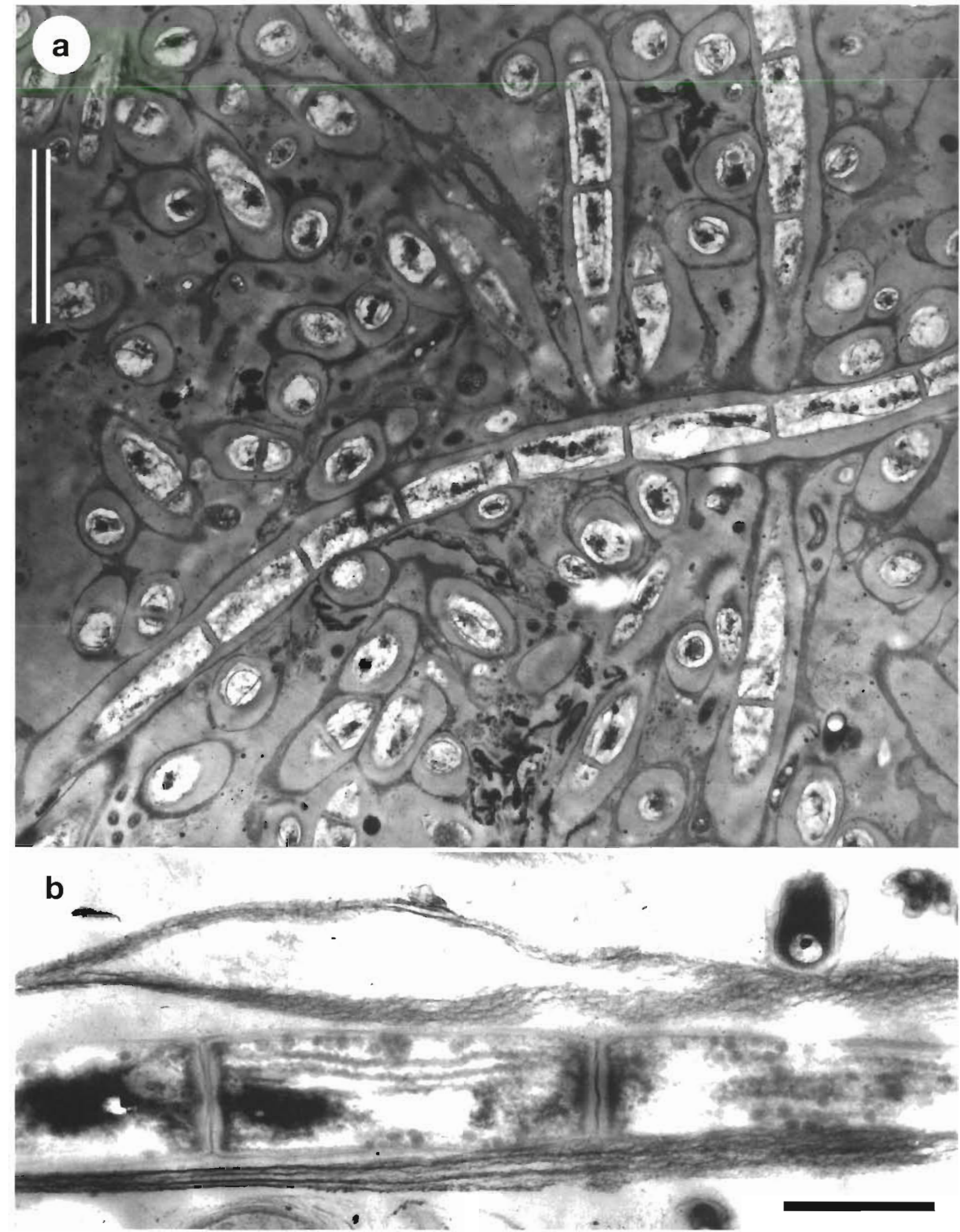

Fig. 5. (a) Section between 0.075 and $0.1 \mathrm{~mm}$ depth dominated by the surface form of Pseudoanabaena. Scale bar: 5 um (b) Pseudoanabaena 'deep morphotype' $1 \mathrm{~mm}$ below the surface. Scale bar: $1 \mathrm{~mm}$ 


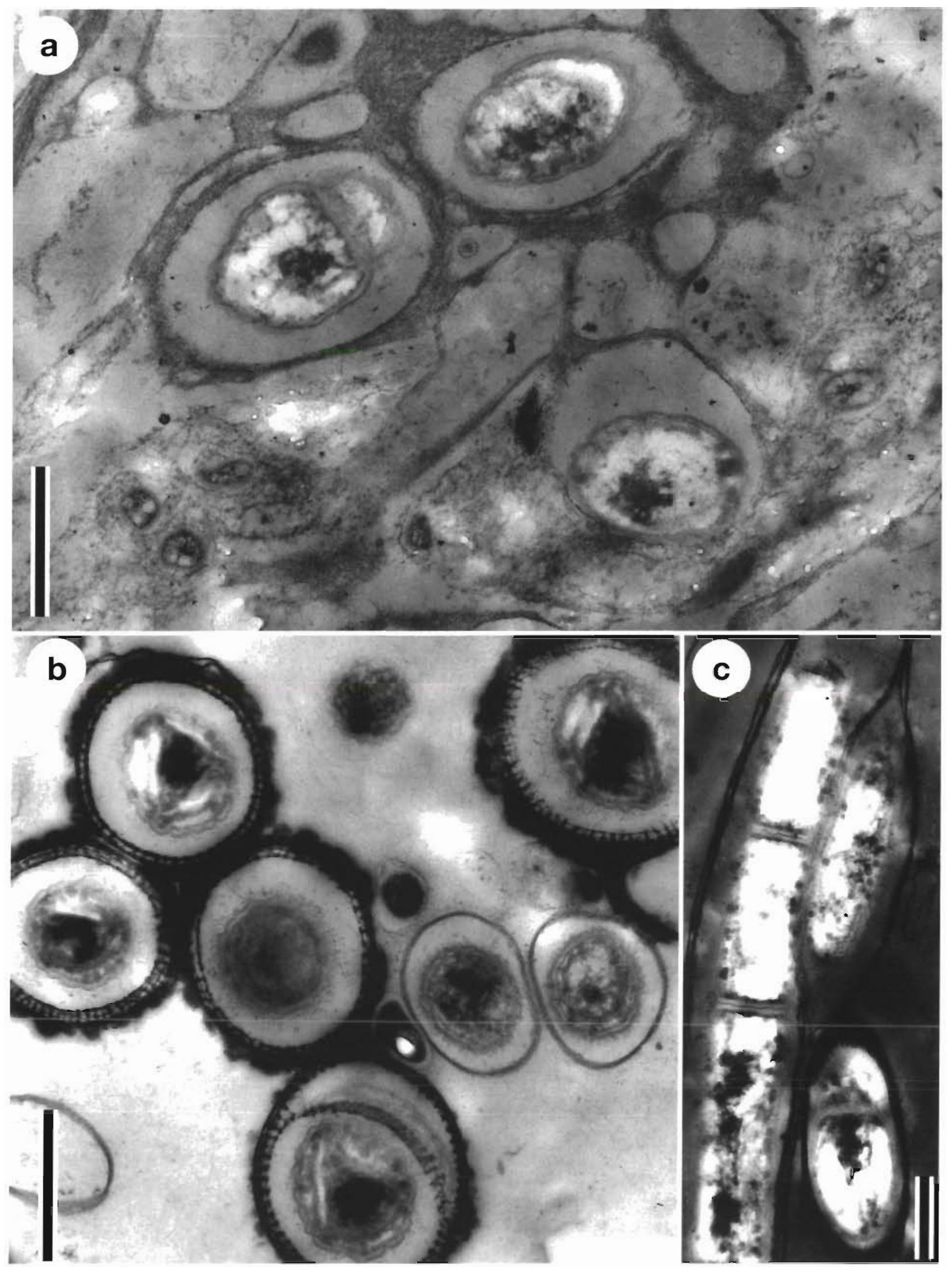

Fig. 6. (a) Section about $0.25 \mathrm{~mm}$ beneath the surface. (b) Bundle of both morphotypes of Pseudoanabaena about 1 mm beneath the mat surface. (c) False branching of a Pseudoanabaena 'deep morphotype' about $1 \mathrm{~mm}$ beneath the surface. Scale bars: 1 im 


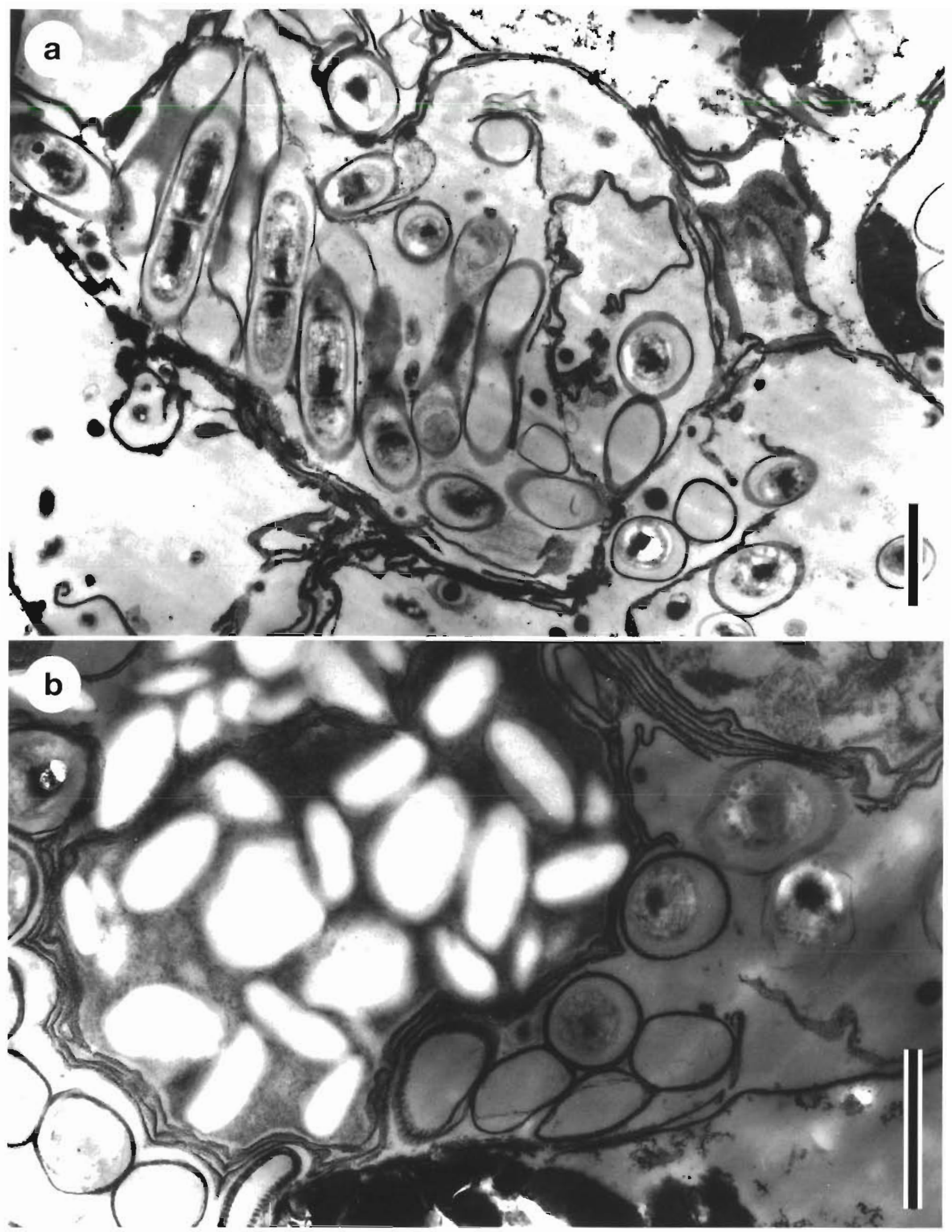

Fig. 7. Several Pseudoanabaena filaments ('deep morphotype') within a common mucous sheath. (b) Unidentified structure surrounded by several concentric layers of mucus. Both photographs are from about $1 \mathrm{~mm}$ beneath the surface. Scale bars: $2 \mu \mathrm{m}$ 
cells had more thylakoids and appeared green, but this was probably only a result of living at greater depth in the mat. However, the filaments also had thicker and more elaborate mucous sheaths and showed false branching within the sheaths so that several concentric sheaths of different 'generations' were found in cross sections (Figs. 5b, 6b, $c \& 7$ a). This form grew in bundles of parallel filaments (Fig. 1e) and dominated the biota from about $0.3 \mathrm{~mm}$ depth down to the bottom of the green zone at about $4 \mathrm{~mm}$ beneath the surface. In situ the bundles tended to have a vertical orientation (Fig. 3b). The fact that both morphotypes of Pseudoanabaena occurred together between 0.3 and $1 \mathrm{~mm}$ depth (Fig. 6b) also suggests that they represent different species. The outer surface of their sheaths was densely populated by attached bacteria (Figs. 1e \& 5b).

Around the transition between the brownish and the light green zones $(0.25$ to $0.35 \mathrm{~mm}$ beneath the surface of the 'parallel layer') carbonate minerals deposited, resulting in a discrete white layer (Fig. 1f). The carbonate layer was easily localised by dripping dilute $\mathrm{HCl}$ on sections such as the one shown in Fig. $1 \mathrm{f}$ and observing the formation of $\mathrm{CO}_{2}$ bubbles. In the 4 mo old mat the carbonate occurred in the form of 100 to $200 \mu \mathrm{m}$ large, white granules (much as described by Dalrymple 1965 for natural mats); in $1 \mathrm{yr}$ old mats these had grown together to form an almost continuous, but perforated, 100 to $200 \mu \mathrm{m}$ thick plate (see also Fenchel 1998b).

The green zone (which became dark green below 1 to $2 \mathrm{~mm}$ ) was, as mentioned above, dominated by bundles of the second morphotype of Pseudoanabaena. However, filaments of Phormidium sp. (Fig. 1d) and colonies of Microcoleus (Fig. 1c) also occurred; the motile Phormidium filaments were mainly vertically oriented like the Pseudoanabaena bundles. In the deepest part of the green zone. Microcoleus filaments often harboured attached colonies of purple sulphur bacteria (Fig. 1c). The green layer also contained chroococcoid cyanobacteria. Purple sulphurbacteria appeared at a depth of 2.5 to $3 \mathrm{~mm}$ and had a maximum density at a depth of around $4 \mathrm{~mm}$ where the mat turned purple.

The mat also included structures which could not be interpreted (Fig. 7b) and various morphologically characteristic but unidentified prokaryotes (examples are shown in Fig. $8 \mathrm{a}-\mathrm{c}$ ).

The dominance of Pseudoanabaena seems unusual in that most previously described mats seemed to be dominated by forms like Microcoleus, Phormidium, Lyngbya, or Oscillatoria. The cell dimensions and ultrastructural details (such as the peripheral thylakoids; see Anagnostidis \& Komárek 1988) clearly shows that the 2 dominating forms did belong to Pseudoanabaena. However, among the previously published TEM photographs of mat components, one presented by
Nicholson et al. (1987, their Fig. 5b) shows characteristics of Pseudoanabaena (length:width ratio of cells, peripheral thylakoids) and it is probably similar to the forms described in the present paper These cyanobacteria may therefore also be an important component of other microbial mats.

The mats studied here were characterised by the apparent absence of filamentous colourless sulphur bacteria which seemed to be present in most other studied cyanobacterial mats (e.g. Jørgensen \& Des Marais 1986. D'Amelio et al. 1989) and the mat surface did not become white in the dark even though the mat surface became anoxic and sulphidic. In the present mats most sulphide oxidation was phototrophic in the light (Fenchel 1998b), but in the dark this process must have been catalysed by inconspicuous colourless sulphur bacteria.

The overall diversity of phototrophs in these mats seemed lower than that reported from studies of natural mats (Nicholson et al. 1987, D'Amelio et al. 1989, Stolz 1990). Certain cyanobacteria which seem to occur in most mats (Lyngbya, Oscillatoria, Spirulina) were absent. Among non-oxygenic phototrophs the purple sulphur bacterium Thiocapsa dominated; green sulphur bacteria were present, but Chloroflexus filaments which have been reported from most other mats were not observed.

Eukaryotic diversity was low and probably to a large extent limited by the probability of surviving the defaunation process of the inoculate (freezing at $-20^{\circ} \mathrm{C}$ see Fenchel 1998a). Diatoms Navicula sp. were initially common in the surface layer, but became rare in older mats. Instead an unidentified, non-motile, 5 to $6 \mu \mathrm{m}$ large spherical green alga, possibly a prasinophyte, was always common in the surface layers of the mats. Amoebae were common and heterotrophic flagellates occurred as did a few species of ciliates, among which only Protocrucia sp. was consistently present and common. The mat also included a variety of unidentified, eukaryotic cysts. Among metazoa an unidentified nematode was consistently present and specimens of the rotifer Colurella sp. were occasionally observed. Altogether, biomass constituted by eukaryotes was too low to be quantified on the microscopic sections.

Fig 9 shows the volume fraction of the mat constituted by the 2 quantitatively dominating components: filamentous cyanobacteria and unicellular (presumably dominantly heterotrophic) bacteria. Chroococcoid cyanobacteria were too rare for confident quantification, but they constituted about $0.5 \%$ of the volume of the upper $0.2 \mathrm{~mm}$. The standard deviations of the individual data points in Fig 9 are 18 and $6 \%$ for filamentous cyanobacteria and 'bacteria', respectively. The volume fraction of the filamentous forms only includes 

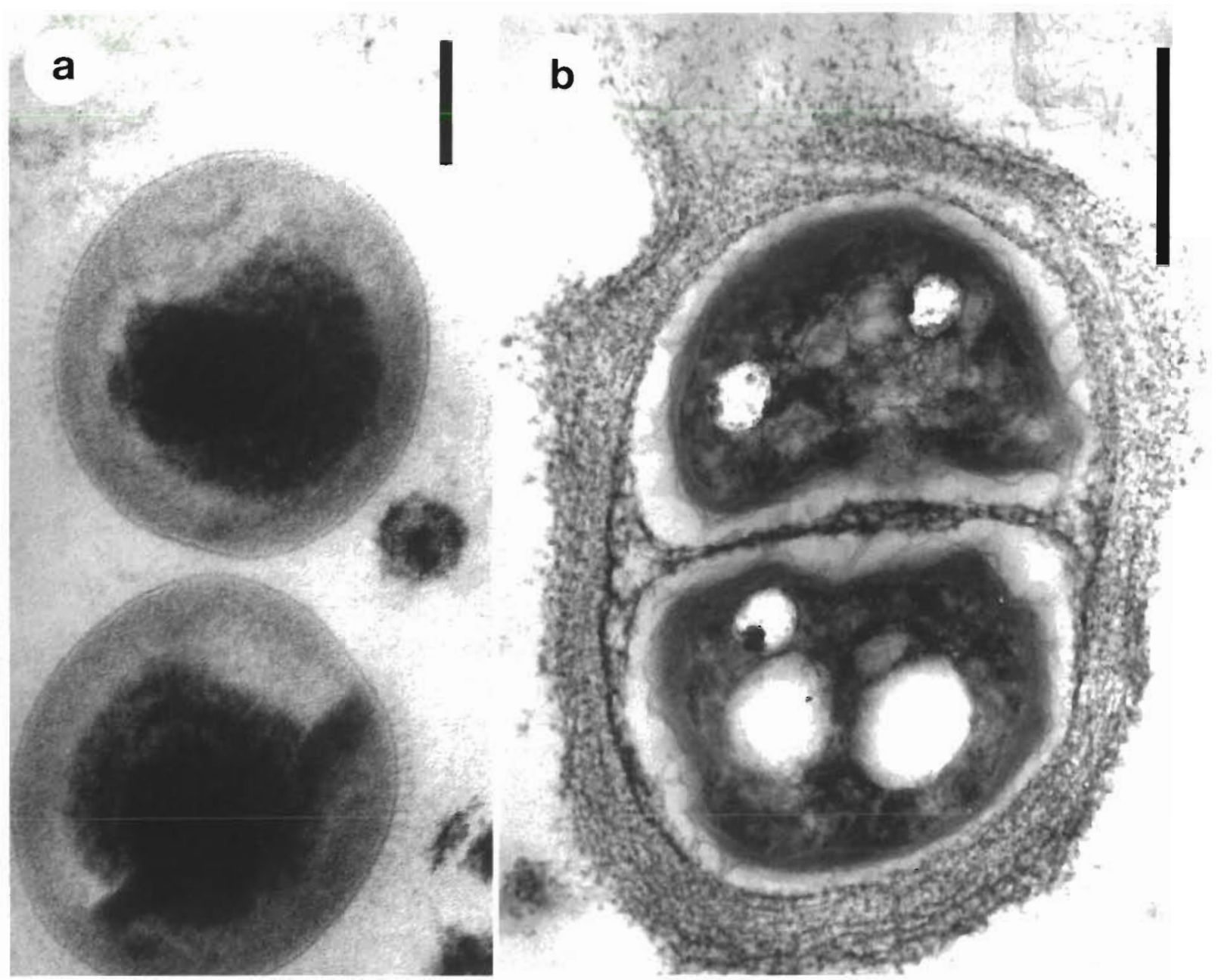

C

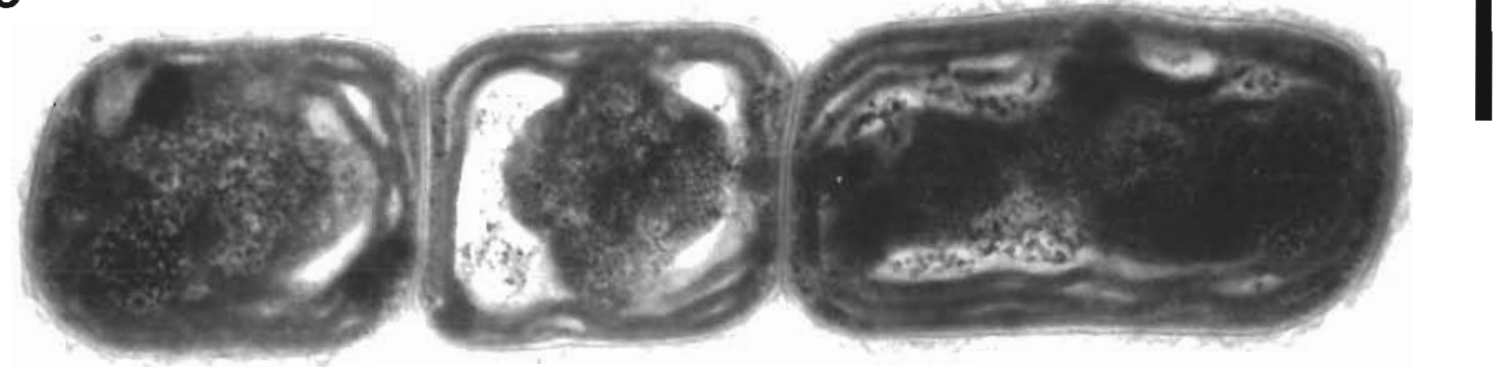

Fig. 8. (a) Small $(\sim 0.2 \mu \mathrm{m})$ prokaryotic organisms which occurred exclusively between 0.05 and $0.1 \mathrm{~mm}$ depth (can be seen in Fig. 5a). Scale bar: $0.1 \mu \mathrm{m}$. (b) Unidentified, presumably phototrophic prokaryote at a depth of 1.5 mm; the colonies contained several cells. Scale bar: $0.5 \mu \mathrm{m}$. (c) Unidentified cyanobacterium, $3 \mathrm{~mm}$ beneath the surface. Scale bar: $0.5 \mu \mathrm{m}$

cells in Fig. 9; if their sheaths are included the values should be multiplied by 2.40 so that e.g. at $0.1 \mathrm{~mm}$ depth the cyanobacteria including mucous sheaths made up 25 to $30 \%$ of the entire volume (not including empty sheaths and diffuse mucus). It can be seen that the mucous pinnacles ( $>0 \mathrm{~mm}$ depth) contained relatively high numbers of bacteria, but few cyanobacterial filaments, and that the density of filaments was highest between 0.03 and $0.2 \mathrm{~mm}$; below this depth the volume fraction of the cyanobacteria remained relatively constant down to about $3 \mathrm{~mm}$ depth. Since the diameter of the dominating cyanobacterial filaments was $1.0 \mu \mathrm{m}$, it can be calculated that the total length of filaments beneath $1 \mathrm{~cm}^{2}$ and down to a depth of $3 \mathrm{~mm}$ was 


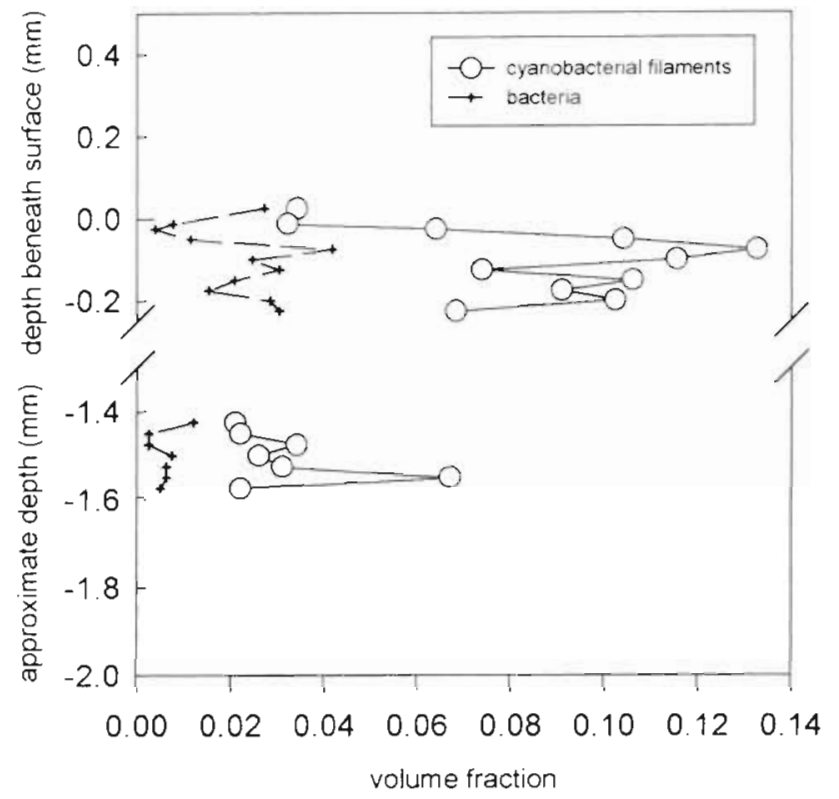

Fig. 9. Volume fraction of cyanobacterial filaments (excluding sheaths) and of unicellular bacteria from the mucous pinnacles (about $30 \mu \mathrm{m}$ above the surface of the parallel layer) and down to a depth of $0.25 \mathrm{~mm}$ and between about 1.4 and $1.6 \mathrm{~mm}$ depth. If sheaths are included, the volume fraction constituted by filamentous cyanobacteria is 2.4 times higher

$13.8 \mathrm{~km}$. Other bacteria constituted on the average $2.3 \%$ of the mat volume at depths down to $0.25 \mathrm{~mm}$ and $0.6 \%$ from 0.25 down to $3 \mathrm{~mm}$ depth. Since the dimensions of the different bacteria varied considerably it was not possible to estimate their mean volume from 2-dimensional sections. However, if we assume that the mean volume of the bacteria is $0.5 \mu^{3}$ (and this is likely to be an overestimate) then the concentration of the bacteria was $4.6 \times 10^{10} \mathrm{ml}^{-1}$ in the surface layers of the mat and $1.2 \times 10^{10} \mathrm{ml}^{-1}$ further down. This corresponds to $4.8 \times 10^{9}$ bacteria beneath $1 \mathrm{~cm}^{2}$ down to a depth of $3 \mathrm{~mm}$.

Vertical profiles of chlorophylls (Fenchel 1998a) show that chlorophyll a concentrations are 4 to 5 times higher between 1 and $3 \mathrm{~mm}$ depth than in the upper $\mathrm{mm}$ of the mat. Since the cyanobacterial biomass is 3 to 5 times higher in the uppermost layer, the chlorophyl content of the cyanobacteria inhabiting deeper part of the mat must be 10 to 20 times higher than that of cyanobacteria inhabiting the surface layers. The thylakoids are more developed in the cyanobacteria further down, and the Pseudoanabaena filaments did not show gliding motility in microscopic preparations (in contrast to the less common Phormidium filaments). Together, these obserwations suggest that the principal phototrophs (which also provide the mechanical coherence of the mat) did not perform vertical migrations in response to changing light conditions, but maintained their vertical position except for the response to the slow vertical growth of the mat, which is only about $2 \mathrm{~mm} \mathrm{yr}^{-1}$ (Fenchel 1998a). The vertical migrations of chemotrophic, filamentous sulphur bacteria in response to the diel vertical migrations of the $\mathrm{O}_{2}$ gradients were a prominent feature of other studied mats (e.g. Garcia-Pichel et al. 1994, Fenchel \& Bernard 1995), but such organisms were absent from the described mat. There was no evidence that the substrate of the mat (foam rubber) was inhibitory to migrations; also mats growing in a similar way on natural sediments yielded an identical composition of the biota (including the absence of filamentous colourless sulphur bacteria). Protozoa are also known to migrate in cyanobacterial mats (and in other sediments) in response to changing $\mathrm{P}_{\mathrm{O}_{2}}$ (Fenchel \& Bernard 1996), but this was not studied.

Acknowledgements. These studies were supported by a grant from the Danish Natural Science Research Council. I am grateful to Ms Jeanne Johansen for technical assistance and to Ms Birgit Brander for preparing specimens for light and electron microscopy and for photographic work.

\section{LITERATURE CITED}

Aherne WA, Dunhill MS (1982) Morphometry, Edward Arnold, London

Anagnostidis K, Komárek J (1988) Modern approach to the classification system of cyanophytes 3 -Oscillatoriales. Arch Hydrobiol Suppl $80(1-4): 327-472$

Dalrymple EW (1965) Calcium carbonate deposition associated with blue-green algal mats, Baffin Bay Texas. Publ Inst Mar. Sci Texas Univ 10:187-200

D'Amelio ED, Cohen Y, Des Marais DJ (1989) Comparative functional ultrastructure of two hypersaline submerged cyanobacterial mats: Guerrero Negro, Baja California Sur, Mexico, and Solar Lake, Sinai, Egypt. In: Cohen Y, Rosenberg E (eds) Microbial mats. American Society for Microbiology, Washington, DC, p 97-113

Fenchel T (1998a) Formation of laminated cyanobacterial mats in the absence of benthic fauna. Aquat Microb Ecol $14: 235-240$

Fenchel T (1998b) Artificial cyanobacterial mats: cycling of $C$, $O$, and S. Aquat Microb Ecol 14:253-259

Fenchel T, Bernard C (1995) Mats of colourless sulphur bacteria. I. Major microbial processes. Mar Ecol Prog Ser 128:161-170

Fenchel T, Bernard C (1996) Behavioural responses in oxygen gradients of ciliates from microbial mats. Eur J Protistol $32: 55-63$

Garcia-Pichel F, Mechling M, Castenholz RW (1994) Diel migrations of microorganisms within a benthic hypersaline mat community. Appl Environ Microbiol 60: $1500-1511$

Javor BJ, Castenholz RW (1981) Laminated microbial mats, Laguna Guerrero Negro, Mexico. Geomicrobiol J 2:237-273

Jørgensen BB, Des Marais DJ (1986) Compettion for sulfide among colorless and purple sulfurbacteria in cyanobacterial mats. FEMS Microbiol Ecol 38:179-186

Jorgensen BB, Revsbech NP, Cohen Y (1983) Photosynthesis and structure of benthic microbial mats: microelectrode 
and SEM studies of four cyanobacterial communities. Limnol Oceanogr 28:1075-1093

Komárek J, Anagnostidis K (1986) Modern approach to the classification system of cyanophytes 2-Chroococcales. Arch Hydrobiol Suppl 73(2):157-226

Komárek J. Anagnostidis K (1989) Modern approach to the classification system of cyanophytes 4-Nostocales Arch Hydrobiol Suppl 82(3):247-345

Nicholson JAM, Stolz JF, Pjerson BK (1987) Structure of a microbial mat at Great Sippewissett March, Cape Cod, Massachusetts. FEMS Microbiol Ecol 45:343-364

Stal LJ, Van Gemerden H, Krumbein WE (1985) Structure and development of a benthic marine microbial mat. FEMS Microbiol Ecol 31:111-125

Editorial responsibility: Gary King,

Walpole, Maine, USA
Stolz JF (1983) Fine structure of the stratified community at Laguna Figueroa, Baja California, Mexico. 1. Methods of in situ study of laminated sediments. Precamb Res 20: $479-492$

Stolz JF (1990) Distribution of phototrophic microbes in the flat laminated microbial mat at Laguna Figueroa, Baja California, Mexico. BioSystems 23:345-357

Stolz JF (1994) Light and electron microscopy in microbial mat research: an overview. In: Stal LJ, Caumette P (eds) Microbial mats. Springer-Verlag, Berlin, p 173-182

Wachendörfer V, Krumbein WE (1991) The fluorescent sediment thin section technique: spatial distribution of microorganisms in North Sea microbial mat systems. Kieler Meeresforsch Sonderh 8:381-388

Submitted: September 13, 1997; Accepted: December 22, 1997 Proofs received from author(s): March 9, 1998 